Dialectologia. Special issue, V (2015), 261-292.

ISSN: 2013-2247

Received 17 April 2015.

Accepted 28 June 2015.

\title{
THE BRETON INFLECTIONAL IMPERSONAL ${ }^{1}$
}

\author{
Milan ReZAC \& Mélanie JouItTEAU \\ IKER UMR 5478 \\ Centre National de la Recherche Scientifique \\ milan_rezac@yahoo.ca / Melanie.jouitteau@iker.cnrs.fr
}

\begin{abstract}
The subject agreement inflection of the Breton verb distinguishes six person-number forms and a seventh impersonal form. The impersonal has the generic and arbitrary uses of the class best studied for Germanic man, French on, and Romance se/si, as well as its Irish cognate. We take up two remarkable aspects of the Breton impersonal. One is recent dialectal extensions of the impersonal morphology to prepositional and nominal inflections, completing the otherwise thoroughgoing parallelism of these three systems characteristic of Breton and related languages. In the theory of impersonals, the extensions have the potential to shed light on the limitation of this class of impersonals to subjects. Our second focus is the phi-features of the impersonal in anaphoric dependencies. Breton bolsters the generalisation that this class of impersonals is deficient in phi-features and thereby unable to antecede personal pronouns. However, recent dialectal developments have resulted in grammars where different personal pronouns have become impersonals, and their convergence has created systems where the impersonal antecedes a remarkably wide but still limited range of pronouns. Our study aims to cover the rich but partial descriptions of these phenomena over the Modern Breton period, bolstered by corpus examples, and to extend it by a pilot study of current native speaker competence.
\end{abstract}

\footnotetext{
${ }^{1}$ We thank the audiences of the $7^{\text {th }}$ Celtic Linguistics Conference (Rennes, June 2012), Workshop on Impersonals (Paris, November 2012), and WEDISYN (Madrid, 2014), the editors, a helpful and keen-eyed reviewer, and the generosity of native speakers we have consulted. This research was partially supported by the projects Towards a typology of human impersonal pronouns (ANR-11-FRAL-0011), AThEME (GA 61345), and Towards a theory of syntactic (micro)variation: Basque and beyond (FFI201451878-P).
} 


\section{Keywords}

impersonal, phi-features, agreement inflection, anaphora, Breton

\section{L'IMPERSONNEL FLEXIONNEL BRETON}

\section{Resumen}

Le système de flexion verbal du breton distingue six formes de personne et nombre, ainsi qu'une septième forme impersonnelle. Cet impersonnel a les usages génériques et arbitraires de la classe des impersonnels bien étudiés du germanique man, du français on et du romance se/si, ou de son cognat irlandais. Nous utilisons deux aspects remarquables de l'impersonnel breton. Le premier est la récente extension dans un dialecte de cet impersonnel aux inflections nominales et prépositionnelles, ce qui complète le parallélisme profond de ces trois systèmes caractéristiques du breton et des langues celtiques. Dans la théorie des impersonnels, ces extensions remettent en cause les limitations de cette classe aux sujets. Le second aspect est l'ensemble des traits-phi de l'impersonnel dans les dépendances anaphoriques. Les faits du breton soutiennent la généralisation que cette classe d'impersonnels est déficiente en traits-phi, ce qui la rend incapable d'antécéder des pronoms personnels. Cependant, des développements dialectaux récents ont aussi donné naissance à des systèmes grammaticaux où différents pronoms personnels sont devenus des impersonnels, et leur convergence a créé des systèmes où l'impersonnel antécède effectivement un ensemble varié mais restreint de pronoms. Notre étude se veut couvrir les descriptions partielles mais riches de ces phénomènes sur la période du breton moderne, complétées par des relevés de corpus et une étude pilote de locuteurs natifs par élicitation.

\section{Mots-clef}

impersonnel, trait-phi, accord, anaphore, breton

\section{Introduction}

There are different "impersonal" expressions in Breton. ${ }^{2}$ All varieties have arbitrary PRO and the implicit agent of the passive. All also have $2^{\text {nd }}$ person generic pronouns, 1). Most but not all use the cardinal unan 'one' as a generic impersonal pronoun, 2). Outside NW-Leon, an den 'the person' tends to be grammaticalised in a

\footnotetext{
${ }^{2}$ Overviews of Breton may be found in Press (2010), including a dialectal sketch, for which also helpful is Hewitt (2002). In citations and the bibliography, we indicate broad dialectal affiliation by combining a compass rose indicator with traditional bishopric terminology, e.g. W-, SW-, and S-Kerne for western Kerne (interfacing with Leon), SW Kerne (Bigouden), and S Kerne (interfacing with Gwened); the "central zone" is a distinctive zone localised in eastern Kerne with adjacent parts of Treger and Gwened. We append to sources specifically describing a particular dialect. Data from our elicitations with is coded \{Initial.Session\}. $A$ and $Y$ are a couple from Kerlouan living in Lesneven, NW-Leon. A-M is from Plougastell-Daoulas and L from Cast, both W-Kerne. B is from Bannalec, S-Kerne/Gwened. French data are M. Jouitteau's unless referenced.
} 
Dialectologia. Special issue, $\boldsymbol{V}$ (2015), 261-292.

ISSN: 2013-2247

similar meaning: in 3), it occurs in a position otherwise unavailable to definites (Jouitteau 2015; ARBRES: impersonnel). ${ }^{3}$

1) Petra e v-malec'h gant ar vilin-se?

what $R$ grind. $2 p$ with the grinder-that

What can you grind with that grinder? (Evenou 1987: 581)

2) Skoet e vez unan...

hit $\mathrm{R}$ is $(\mathrm{H}) .3 \mathrm{~s}$ one

One is shocked ... (Seite 1998: 38)

3) Ben'vez (an nen) klañv(Yann), ne vez ketgwelet ken.

when is $(\mathrm{H}) .3 \mathrm{~s}$ the man sick Yann NEG is $(\mathrm{H}) .3 \mathrm{~s}$ not seen anymore

When a person/Yann is ill, he is seen no more. \{B. 2009/1\}

Here we are concerned with an impersonal that joins the six person-number inflections of the finite verb as a seventh member, the $-r$ inflection in 4 ), and its counterparts in prepositional and nominal inflection.

4) Arabat klask rebech d'ar re all, pa ne vezer ket didamall.

forbid search reproach to the ones other when NEG is(H).IMP not blameless

One must not seek to reproach others when one is not blameless oneself. \{A.Q1,2\}

This impersonal in Breton belongs to a distinctive class of impersonals we will call $\rho$-impersonals, including French on that we use to illustrate. They have the following properties. $^{4}$

\footnotetext{
${ }^{3}$ Glosses indicate person-number inflection by person and number, e.g. $1 \mathrm{~s}$ for $1^{\text {st }}$ person singular, but independent pronominal morphemes as pronouns; the verbal base indicates tense, e.g. is vs. was; after is/was, (H) is habitual, (S) individual-level, (L) stage-level or locative, bare is/was a special invariant form, see section 2; R is a preverbal particle, NEG is the first element of a bipartite negation, REFL is the reflexive-reciprocal clitic.

${ }^{4}$ For the class and its differentiation from generic and arbitrary impersonals, see Cinque (1988), Egerland (2003), Malamud (2012), and literature there. For reasons of space, we are minimal about the theory of and literature on $\rho$-impersonals; both are more fully discussed in Rezac \& Jouitteau (2015), henceforth R\&J. There is no fixed term for the class: we use $\rho$-impersonal for its similarity to larger $r$ impersonal class of the typological literature (Siewierska 2011).
} 
(I-a) Both generic and arbitrary uses. The generic use 5) occurs in the scope of quantifiers like often or the silent generic operator. The $\rho$-impersonals covaries with the quantifier quantifier in the manner of a weak indefinite or bare noun and pronominal anaphora to them to give rise to quantificational variability. The arbitrary use 6) occurs elsewhere. It is translatable by a weak indefinite or bare noun, or by a universal, and pronominal anaphora to them. ${ }^{5}$

A Douarnenez, quand on ${ }_{i}$ aprend le breton, on ${ }_{i}$ l'aprend $\varnothing /$ souvent à ses samis.

In Douarnenez, when people learn Breton, they $\varnothing /$ often teach it to their friends.

$\rightarrow$ All/Many who learn Breton teach it to their friends. (quantificational variability)

6) On n $_{i}$ 'a dit qu'on ${ }_{i / k}$ ne s'est pas accordé les uns avec les autres.

$i$ : People $e_{i}$ told me that they $y_{i}$ did not agree with each other.

$k$ : I was told ${ }_{\text {agent=i }}$ that people $e_{k}$ did not agree with each other.

(I-b) Specific uses. These are found with some but not all $\rho$-impersonals, and have the properties of a personal pronoun. French on a specific use with the properties of the older $1 p$ subject clitic nous, which it mostly replaces. In 5), on can be focus doubled by the strong pronoun $1 p$ nous as nous on, and the anaphor ses can be $1 p$ notre, changing the translation to 'we ... our'. 6

(II) Reduced referentiality on non-specific uses. Here we focus on absence of person and number phi-features, which makes an impersonal neutral about them and prevents anaphoric relationships to expressions specified for them. In 5), on can range over the speaker and addressee as well as third parties, unlike ils 'they' or nous 'we' in its place, and likewise over atoms or pluralities. The anaphoric on and son in these examples cannot be replaced by a fully phi-specified pronoun such as $3 p$ leur 'their'. $\rho$ impersonals are not as referentially reduced as the implicit agent of the passive, for

\footnotetext{
5 The terms generic and arbitrary are standard (Egerland 2003). Generic includes all adverbial quantification, including when it does not support generic impersonals, Yesterday afternoon, if people/\#you sent me an email, I answered within the hour. Determiner quantifiers with $\rho$-impersonals are less understood; see $R \& J$.

${ }^{6}$ See Kayne (2010: chapter 7), R\&J for the 1p behavior of French on, Cinque (1988) for Italian si.
} 
they can form anaphoric dependencies with phi-reduced expressions: in these examples, with the s-pronoun ses, lacking number, and the reciprocal, lacking person. ${ }^{7}$

(III) Pronominal status for Condition C.

(IV) Other restrictions partly under debate: to humans; to subjects; in arbitrary uses to agents.

$\rho$-impersonals may be contrasted with generic impersonals like English one and generic $2^{\text {nd }}$ person, limited to certain generic contexts: *One learned Breton. $\rho$ impersonals may also be contrasted with arbitrary impersonals like arbitrary they that cannot vary with quantifiers. To a good first approximation, $\rho$-impersonals behave as if both weak indefinites or bare nouns and anaphora to them, and semantic approaches to them usually pursue this parallelism (e.g. Chierchia 1995; Mendikoetxea 2008; R\&J).

$\rho$-impersonals have diverse origins and morphosyntax. Of the two best-studied types, one originates in bare singular nouns meaning person: cognates of Germanic man and of French on. Grammaticalisation has led to pronominal status and and partial loss of phi-features (Giacalone Ramat \& Sansò 2007). The other has followed a wholly different path, that of reflexive clitics from transitives to inchoatives to passives to impersonals, giving Romance and Slavic si/se impersonals (Giacalone Ramat \& Sansò 2011; Meyer 2010). Among $\rho$-impersonals, there are minimal contrasts on the specific use: Italian si has a 1p specific use like on, but its Spanish cognate se has none. Most known $\rho$-impersonals resolutely have the human and subject restrictions in (IV), and some resistance to non-agentive arbitrary uses.

In what follows, we characterise the Breton $\rho$-impersonal, starting from its clearest instance, the verbal inflections, proceeding to their recent expansion to prepositional inflection, and to recruitment of the definite article ar as an impersonal pronoun. Our focus is the history of and variation on these developments, and their contribution to the debated properties in (IV). We then study phi-incompleteness (V) through anaphoric relations.

\footnotetext{
${ }^{7}$ We establish these properties of on and their implication in limits on anaphoric dependencies in R\&J. Other aspects of reduced referentiality involve for instance neutrality about novelty-familiary and maximality.
} 


\section{Verbal inflection}

The Breton finite verb inflects for six subject person-number combinations given in Table 1. The impersonal is the seventh member of this paradigm. Morphologically, the impersonal inflexion is $-r$ in the present and future, $-d$ in the preterite (literary), imperfect, and conditional present and past. In Breton, agreement inflections appear only under pro-drop or doubled by emphatic enclitic pronouns, while full DPs combine with the uninflected form in a phenomenon known as the complementarity effect. The impersonal has no pronominal or other counterpart outside the inflection. Table 1 also gives parallel prepositional and nominal systems, which we take up later, and the object proclitic system that now mostly remais only in NW-Leon and SE-Gwened varieties. There are minor asymmetries between the systems that do not concern us here; one worth noting is that among full DPs count strong pronouns, but strong pronouns can only occur in the preverbal position and so are never prepositional objects or possessors. $^{8}$

\begin{tabular}{|c|c|c|c|c|}
\hline & $V+$ subject & object + V & possessor $+\mathrm{N}$ & $P+$ object \\
\hline $1 \mathrm{~s}$ & $\begin{array}{ll}\text { rann-an } & \text { 'I } \\
\text { share' } & \end{array}$ & $\begin{array}{l}\text { em/ma rann 'shares } \\
\mathrm{me}^{\prime}\end{array}$ & ma rann 'my share' & $\begin{array}{l}\text { gan-in 'with } \\
\text { me' }\end{array}$ \\
\hline 1s+emph. & rann-an-me & em/ma rann-me & ma rann-me & gan-in-me \\
\hline $2 s$ & rann-ez & ez/da rann & da rann & gan-it \\
\hline $3 s(m, f)$ & rann & $e(r)$, he rann & e, he rann & gant-añ, -i \\
\hline $1 p$ & rann-omp & hor rann & hor rann & gan-eomp \\
\hline $2 p$ & rann-it & ho rann & ho rann & gan-eoc'h \\
\hline $3 p$ & rann-ont & o rann & o rann & gant-o \\
\hline IMP & rann-er & N/A & $\mathrm{N} / \mathrm{A} \rightarrow$ ar rann & N/A $\rightarrow$ gan-eor \\
\hline full DP & rann ar chas & rann ar chas & rann ar chas & gant ar chas \\
\hline & $\begin{array}{l}\text { 'the dogs } \\
\text { share' }\end{array}$ & 'shares the dogs' & $\begin{array}{l}\text { 'the share of the } \\
\text { dogs' }\end{array}$ & 'with the dogs' \\
\hline
\end{tabular}

Table 1. Breton inflectional morphology (standard, save developments in $\rightarrow$ )

\footnotetext{
${ }^{8}$ The complementarity effect and emphatic enclitics in Breton are discussed in Anderson (1982), Stump (1984, 1989), Borsley and Stephens (1989), Jouitteau \& Rezac (2006), and in literature on other Celtic languages, seminally McCloskey \& Hale (1984) on Irish \& Rouveret (1991) on Welsh.
} 
The $r / d$-inflection of the verb is part of the paradigm of every tense-mood combination, save the imperative, in Middle Breton (Hemon 2000), in early modern varieties (e.g. Rostrenen 1738), and in some current ones (W-Kerne/Leon, Kervella 1995 [1947]: §190; NE-Treger, Leclerc 1986 [1906]: 68,4; NE-Goueloù, Le Coadic 2010: 30). In some varieties, $-r$ has encroached on the territory of $-d$ (Ernault 1897; NW-Leon, Sommerfelt 1921, NE-Treger Le Dû 2012). ${ }^{9}$ However, the inflection has been losing ground over the twentieth century. The dialectal Atlas of Le Roux (1927), investigating translations of French on, suggests loss in certain tenses, notably in the future as compared to the present, loss with particular verbs, and more general loss in $\mathrm{E} / \mathrm{SE}$ varieties, to alternatives like the passive. Already at the turn of the twentieth century, the $r / d$-inflection is an archaism in SE Gwened (Guillevic \& Le Goff 1902: 47, but not yet Le Bayon 1986 [1878]). Among current varieties, detailed descriptions show complete loss in dialects of SE-Gwened (Cheveau 2007; Ternes 1970; Crahe 2013) and the central zone (Plourin 1982: 664, 682; Humphreys 1995), elsewhere limitation to the present tense and to certain verbs (SW-Kerne, Goyat 2012: 4.7; W-Kerne, Ploneis, 1983: 165; central, Wmffre 1998: 2.24; S-Kerne, Jouitteau 2015, ARBRES; for a nuanced description, central Favereau 1984, cf. 1997: §472). The loss of the $r / d$-inflection does not go together with attrition of other subject inflections. ${ }^{10}$

\footnotetext{
${ }^{9}$ The impersonal inflection is absent from the verb kaout (endevout) 'have'. The gap is due to the origin of the agreeing forms of have in the existential form of be, object proclitics, and nominative subjects restricted to the $3^{\text {rd }}$ person, known as the mihi est type. The oblique + nominative profile remains in SE and NW dialects, but by and large the verb has aligned with plain transitives, first in syntax where objects receive object case, and then in inflection that has been regularised to suffixes, e.g. hon-eus-i gwelet us-be/have-3p.nom seen, to neus-omp o gwelet have-1p them seen (Jouitteau \& Rezac 2006, 2009). One might expect the regularisation to add the $-r /-d$ inflection, especially since the have/beperfect is the only productive punctual past tense, and indeed Ernault (1884: 202) gives a-m-eur cruciffiet R-me-be/have.IMP crucified 'who has crucified me' as an archaism without further citation. However, by and large regularisation of have coincides with loss of the $r / d$-inflection.

${ }^{10} \mathrm{~A}$ reviewer raises the question of reasons for the loss of the $r / d$-inflection. Influence of French is possible, with its $1 / 2 / 3+s / p$ subject but no impersonal inflection: the period of $-r /-d$ loss roughly coincides with the introduction of French in primary education and the development of Breton to the recessive language of bilinguals. However, other changes took place in Breton over roughly the same period that go contrary to expected influence of French: the object clitics, for instance, have been replaced by strong pronouns. Internal dynamics of the Breton system may well have been a factor in the loss of $-r /-d$, notably use of the passive which systematically overlaps and interacts with the impersonal (Hewitt 1997; Jouitteau 2015). The Breton passive is more common and neutral than in French, more widely available with intransitives, and particularly common in generic use with the habitual form of the be copula.
} 
The origin of the $r / d$-inflection differs from that of man/on and se/si impersonals (Cowgill 1983). The $-r$ ending has cognates in Indo-European mediopassives, such as Latin videtur 'she is seen', and 3p actives, Latin viderre 'they have seen', whose mutual relationship remains debated (Clackson 2007). The $-d$ ending descends from the past participle in -t-, usually forming periphrastic passives with be, Latin vistus est 'she is seen'. The two gave a Celtic formation with passive syntax for transitives with $3^{\text {rd }}$ person objects, promoted to agreeing nominative, and impersonal syntax otherwise, for transitives with accusative $1^{\text {st }} / 2^{\text {nd }}$ person objects and availability for intransitives. This stage is reflected in Old Breton, and rare Middle Breton examples with passive characteristics like agent by-phrases. By and large in Middle Breton, and strictly in modern varieties, the syntax is impersonal rather than passive. Cognate inflections have undergone a similar development (Welsh, Borsley et al. 2007: 8.3.3; Irish, McCloskey, 2007).

Syntactically, $r / d$-forms participate in structures where the impersonal argument behaves as a regular pronominal subject (Anderson 1982; Hewitt 2002). Among intransitives, $r / d$-inflections are found for all verbs, unergative, unaccusative, psychverb, passive and copula: ${ }^{11}$

7) Plijout a reer din $p a$ vezer tener. please $\mathrm{R}$ do.IMP to.1s when is(H).IMP tender One pleases me when one is tender. $\{$ A.Q1\}

8) Goude an abadenn kanañ e houlenner alies diganin mond da sinañar bladenn. after the session singing R ask.IMP often from.1s go to sign the disk I am often asked to go sign the disk after a concert. \{A.Q2\}

9) Agreiz m'edon gant valein, e teujot d'am c'herc'hat ... at middle as was(L).1s with my lunch $\mathrm{R}$ came.IMP to me search As I was in the middle of my lunch, someone/people came to look for me. (Morvan 1894)

The verb be is of particular interest for its range of forms (Favereau 1997: §407ff; Hewitt 2002, ARBRES: emañ). In the present and imperfect, be distinguishes unmarked

\footnotetext{
${ }^{11}$ This include oblique experiencer please-type verbs, excluded in Irish (McCloskey 2007).
} 
Dialectologia. Special issue, $\boldsymbol{V}$ (2015), 261-292.

ISSN: 2013-2247

and habitual aspects, the latter glossed $(\mathrm{H})$, and both have their impersonal. The present and in NW-Leon the imperfect moreover distinguish two stems, both with $r / d$ inflections: one for the individual-level copula and passive and perfect auxiliary 10), present eur/oar and imperfect oad, glossed (I) and one for the stage-level copula 11) and progressive auxiliary 12 ), present emeur and imperfect edod, glossed $(\mathrm{H}) .^{12}$

10) Eet eur ${ }_{\mathrm{i}} \quad$ da $\mathrm{PRO}_{\mathrm{i}}$ gerhed an Aotrou ' $n$ Eskob

gone is(I).IMP to seek the lord the bishop

Someone/people went to fetch the bishop. (Fave 1989)

11) Edod neuze er XVIlved kantved.

was(L).IMP then in.the $17^{\text {th }}$ century

[Describing someone's life:] It was then the $17^{\text {th }}$ century. (Seite 1998)

12) Emeur o c'hortoz ac'hanon.

is(L).IMP at waiting of.1s

Someone/people/they is/are waiting for me. (Hélias n.d.a.), \{A.Q1\}

10)-12) are of interest because they weaken the generalisation that $\rho$ impersonals are restricted to agentive subjects in arbitrary contexts (Cinque 1988; Egerland 2003). Their French translations likewise allow the $\rho$-impersonal on (R\&J).

Active transitives with impersonal agents align on all points with other active transitives against passives (Anderson 1982; Hewitt 2002). The external argument of a transitive cannot be realised by a by-phrase, unlike the agent of the passive which very frequently is. ${ }^{13}$

Eul lizher a skrived (*gant an den).

a letter $\mathrm{R}$ write.IMP with the man

(Some)one was writing a letter (*by the man). (Anderson 1982)

\footnotetext{
${ }^{12}$ With full DP subjects, non-habitual present uses invariant zo is used if preverbal, eus if postverbal and indefinite, otherwise $3 \mathrm{~s}$ forms of appropriate be's. Varieties may resist the form eur/oar, and habitual ver or locative emeur takes its place (Favereau 1997: §410), and further emeur may be replaced by ver (Favereau 1984).

${ }^{13}$ See McCloskey (2007) for Irish, Borsley et al. (2007: 8.3.3) for Welsh: in both the syntax of impersonals is essentially active, but with some variation on the possibility of by-phrases (cf. Anderson 2002; Hewitt 2002).
} 
The direct object of an impersonal verb has coding of objects in transitives. The active codes it by object proclitics or strong pronouns based on $a$ - 'of'. The passive promotes it to pro-drop inflection or unmarked strong pronouns.

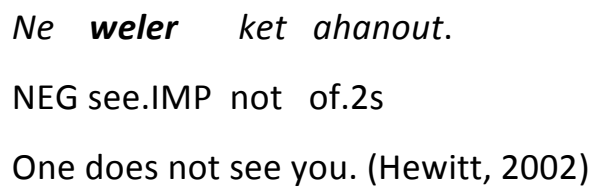

The impersonal subject antecedes obligatory control PRO 10), 15), the reflexivereciprocal clitic en em analogous to French se 16), phrasal reciprocals 17), even floating quantifiers 18), 19), as well as impersonal anaphora to which we return. ${ }^{14}$ As far as we can tell, the implicit agent of the Breton passive is like that of English and French in never anteceding any of these elements save complement PRO.

15) Ne ouezer ${ }_{\mathrm{i}}$ ket mui petra $\mathrm{PRO}_{\mathrm{i}}$ ober.

NEG know.IMP not anymore what

One doesn't know what to do anymore. (Anderson 1982); \{A.Q2\}

16) En em zikour a reer etre amezeien.

REFL help $R$ do.IMP between neighbours

Neighbours help each other. (Fave 1998)

17) Ne blij ketdin pa gomzer an eil ouzh egile (diwar-va-fenn).

NEG please.3s not to.1s when talk.IMP the second to other (from-my-head) I don't like it when people talk to each other (about me). \{A.Q2\}

18) eur penn-brazbennageo peogwir emeur toud o hond 'benn ma en em gavo.

a head-big some is(I).3s because is(L).IMP all at go so that REFL will.find.3s

It's someone important because people are all going to meet up. (Gouedig 1984)

19) An holl a oar breman Seznec a zo divlamm, ha goulen a reer holl terri eul lezen-gamm. the all $R$ know.3s now $S \quad R$ is blameless and ask $R$ do.IMP all break a law-bent All know now that Seznec is innocent, and people all ask to abrogate a false law.

(traditional song), $\{$ A.Q1, Q2 $\}$

\footnotetext{
${ }^{14}$ In French, impersonal on can license floating quantifiers that do not have number concord (R\&J). Breton has no number concord. In 19), speaker-exclusion by adding ouzomp 'at.us' after holl, i.e. ask us, still allows holl $\{$ A.Q2\}.
} 
There is one limit on syntactico-semantic dependencies of the $r / d$-form: the antecedence of pronominal anaphora. This is characteristic of $\rho$-impersonals generally on their non-specific uses. In R\&J, we argue that it follows from the poor content of $\rho$ impersonals, including deficient phi-specification (cf. McCloskey 2007). PRO, the reflexive-reciprocal clitic, phrasal reciprocals, and floating quantifiers are all themselves deficient in phi-features, at a minimum person as they can be used with an antecedent of any person. The phi-specification of the Breton $\rho$-impersonal and its interaction with anaphoricity is studied in section 5 .

Examples above show the $r / d$-forms in generic and arbitrary uses, and others are given in section 5. Specific uses, parallel to the French $1 p$ on, do not seem to exist (Hewitt 2002). There are indeed uses in contexts where the referent is clear and may be we, as in 20), but, as Hewitt points out for a similar example, they are associated with an obliqueness that does not characterise specific on. This is so for our consultants as well: 21 ) is used obliquely to avoid direct reference. $1 p$ doubling and $1 p$ anaphora are essentially impossible, though we take up this question in more detail in section 5. Apparent specific uses are simply extensions of arbitrary uses, in the same way as indefinites may be so extended in Someone's sulking, aren't we?; they may be called pseudospecific (McCloskey 2007).

20) Ale, poent sevel, bugalez, poent sevel! - "Ya, ya! o hond emeur!" time rise children time rise yes, yes at go is(L).1p Come on, time to get up, children, time to get up! - Yes, yes! Coming! (Gouedig, 1984)

21) [Women on the bus are giggling and pointing to me. I tell my friend:]

Emeur o komz an eil ouzheben (diwar-va-fenn). is(L).IMP at speak the second to other.FEM from-my-head They are talking to each other about me. $\{$ A.Q2\}

The $r / d$-form of the verb, like $\rho$-impersonals generally including French on, are 
restricted to humans (Hewitt 2002). ${ }^{15}$ Like on as well, they may be satisfied by atomic individuals, see (50) later for a clear example, or by pluralities, required by the reciprocals in generic (17) and arbitrary (21) and by floating quantifiers in (18), (19).

\section{Prepositional inflection}

The Breton person-number inflection of verbs has its parallel in prepositional inflection in Table 1. In pre-modern Breton and current NE, SE, and central dialects, there is no counterpart to the verbal $r / d$-inflection in prepositional inflection. Prepositions may then make use of the form an unan as an impersonal anaphor to the verbal $r / d$-form, which we discuss in the next section:

Pa labourer évid ann-unan, é labourer gwella ma c'heller.

when work.IMP for IMP-one $\mathrm{R}$ work.IMP best as can.IMP

When one works for oneself, one works the best one can. (Hingant 1868: §125)

However, some modern NW-Leon and SW-Kerne dialects have innovated impersonal inflection for prepositions, attaching the $-r$ ending of the verbal impersonal to the $1^{\text {st }} / 2^{\text {nd }}$ person plural base of inflected prepositions: gan-eor like $2 p$ gan-eoc' $h$. Falc'hun (1981 [1963]: 437-8) notes the first forms in Leon and Kerne writers and grammarians in the early 1940 s and deems them recent. He attributes them to phonological convergence of the impersonal $-r$ of verbs upon the change $[r]>[\mathrm{R}] /[\mathrm{b}]$ with $2 p-c^{\prime} h[x]$; the generic use of $2 p$ might have helped (see section 5 ). Falc'hun's hypothesis accounts for limitation of the forms to certain late modern varieties of Breton, the lack of counterparts in other Celtic languages, which do have inflected prepositions, and the use of the $1 p / 2 p$ stem of the preposition shown in Table 1 . The prepositional $r$-forms are emphasised in influential grammatical notes by the NW-Leon dialect writer V. Fave $(1943,1986,1998)$ and is common in his writings, e.g. Fave

\footnotetext{
${ }^{15}$ In this it contrasts with Irish, where the impersonal inflection of the verb is also used with inanimate causers as It wrecked him on the coast of China once (McCloskey 2007). Syncretism with a quasiexpletive may be a possibility.
} 
Dialectologia. Special issue, $\boldsymbol{V}$ (2015), 261-292.

ISSN: 2013-2247

(1989), as well as the writings of V. Seite $(1985,1998)$ of the same origin. However, it is also noted in grammatical observations across the W/SW-Kerne area, Nedelec (1943), ar Gow (1963), Trépos (2001 [1968]), further cited in e.g. Morvanou (1978: 215, 1980: 468), Favereau (1997: §767).

In Fave's use, the $r$-inflection extends to all inflected prepositions, from core arguments to verbal and nominal adjuncts, both when anaphoric to a verbal $r$-form or arbitrary PRO and when independent:

23)a ar pez a gaser ganeor a gaver

that piece R send.IMP with.IMP R find.IMP

What one takes with one, one finds.

b Ganeor an-unan eo e vez armuia aboan

with.one IMP-one is(I).3s $\mathrm{R}$ is $(\mathrm{H}) .3 \mathrm{~s}$ the most of pain

It's with oneself that one has most trouble. (C'est avec soi-même qu'on a le plus de mal.)

24)a $\mathrm{Pa}$ vezer o tastum danvez deor an-unan

when is(H).3s at gather stuff to.IMP IMP one

When one gathers stuff for oneself. (Quand on thésaurise pour soi.)

b Pa gred deor PRO beza an-unan.

when believe.3s to.IMP PRO be IMP-one

When one thinks that one is alone.

25)a Ne gaver ketatao tud hegarad eveldoran-unan.

NEG find.IMP not always people cheerful like.IMP IMP-one

One does not always find people as cheerful as oneself.

b Estregedor a zo pinvidig.

except.IMP R is rich

Others than oneself are rich. (D'autres que soi sont riches). (Fave 1998)

We have confirmed the productivity of these $r$-forms of prepositions with a NWLeon speaker originally from Kerlouan but living in Lesneven in 2012. The forms were inaccessible at the beginning of the initial elicitation, unlike verbal $r / d$-inflections, but emerged at its end with activation of his childhood grammar, and subsequent 
elicitations revealed strong and consistent grammaticality judgments. The speaker's wife by contrast lacks $r / d$-forms of both verbs and prepositions, understanding them as generic $2 p$ thanks to a phonological collapse of final $-r$ and $2 p-c^{\prime} h$ in her dialect but not that of her husband. For half century, each member of the couple has been using a different impersonal without the other noticing. We report details in section 5 .

The innovation of an impersonal inflection on prepositions is of great potential interest for the study of $\rho$-impersonals. The usual view is that $\rho$-impersonals are restricted to subjects, while generic impersonals have no such restrictions. ${ }^{16}$ There generalisation is poorly understood, but there is considerable force to it: when German and Romance 'person' nouns have grammaticalised as $\rho$-impersonals, they are limited to subject positions, such as German and Swedish man, but when they have grammaticalised as generic impersonals, Icelandic mađur, they occur more freely (Egerland 2003). However, McCloskey (2011) has raised possible counter-examples from inflectional impersonals in Nahuatl (Andrews 2003). For Breton, we do find an extension of $-r$ from verbs to prepositions, but to prepositions that, like the verb, inflect. Yet at this point, all our examples of the prepositional $r$-form are generic. It may thus be that the prepositional $r$-form is a generic impersonal, and its anaphoric relationship to the verbal $r / d$-form is that of the German nominative man to generic ein- 'one' (Cabredo-Hofherr 2008). That too would speak to the restriction of $\rho$ impersonals to subjects, for the $\rho$-impersonal inflection would have become genericonly when extended from the subject to the prepositional object. ${ }^{17}$

\section{Possessive proclitic}

The possessive proclitic system of Breton shows a strong parallelism with verbal and prepositional inflections: see Table 1. A pronominal possessor must be a

\footnotetext{
${ }^{16}$ Non-subject one is sometimes given as ungrammatical, and in it is in 26) photograph one, but not in general: One had the absurd feeling it could follow one; One found oneself running as one entered it ; The staring dial faces ... gave one the impression of looking at ... (C.S. Lewis) ; ... a pinkness of the sort that made one's breath catch in his throat (Clifford D. Simak). By contrast, on and man are categorically impossible as non-subjects.

${ }^{17}$ Fave translates the prepositional $r$-form either by on, or by soi, which is itself not an $\rho$-impersonal but a logophor to a centre unspecified for phi-features (simplifying somewhat: see R\&J with literature).
} 
possessive proclitic, possibly doubled by an emphatic enclitic, but not by a full DP. Conversely, a full DP possessor occurs in the so-called construct state, possessumpossessor, where the possessum cannot have the definite article $\left({ }^{*}\right.$ al) labour an dud 'the work of the people'. Most sources mention no proclitic counterpart to the impersonal, and we would expect ineffability, as happens for the object proclitic in French 26). However, some dialects have recruited the definite article an as an impersonal counterpart to other possessor proclitics. ${ }^{18}$

26) *En voyage on me demande toujours que je _ photographie.

*In travel one always asks me that I photograph _.

(cf. Kayne 2000: 177)

Before we turn to it, we need to discuss the form an unan, litt. 'the one', already seen in 22). Breton has emphatic/anaphoric expressions of the form possessive proclitic + unan, similar French même-forms. Ordinarily, they double a controller, for instance the possessive proclitic, save in structures where there can be no controller, when they serve as anaphora. ${ }^{19}$ In 27), it is not possible to replace the first ma with the definite article ar, because it would leave ma-unan without an antecedent, nor is it possible to omit the first $m a$, as that would give the possessum-possessor construct state and ma unan cannot be the possessor in it. Grammars and dictionaries often note that the ma unan series is completed by an unan, where an is the definite article, in order to double impersonal controllers, as in 28). However, unlike ma unan, an unan can occur as a full DP without any controller, both as possessor 29) and as subject 30). It recalls then English one, including the 3 s anaphor in 30 ) (see (61) below). ${ }^{20}$

\footnotetext{
${ }^{18}$ The definite article as the forms al before $I$, an before coronals, vowels, and $h$, ar before labials, palatals, and velars; an is usually cited as the basic form.

${ }^{19}$ Our description is tentative; see Stephens (1990) for use as local anaphora, and Gros (1984: 187) for examples. As controller counts: agreement inflection of verbs and prepositions, object and possessive proclitics, the subject combining with $3 s$ inflection under the complementarity effect, and the whole DP if the unan-form is attached to it.

${ }^{20}$ Grammars give scant information: for instance an unan is only mentioned in Kervella (1995 [1947]: $\S 436$ ), and given with the reflexive-reciprocal clitic as antecedent in Hemon (2000: §58). It usually fails to be mentioned in otherwise comprehensive descriptions outside NW-Leon, e.g. NE-Treger Le Clerc (1986 [1906]), Le Dû (2012), SW-Kerne Trépos (2001 [1968]), Goyat (2012), SE-Gwened Guillevic and Le Goff (1902), Cheveau (2007), central Humphreys (1995), Favereau (1997: §258), the last contrasting its absence in Poher with Fave. It is not reported among the paradigm of unan-forms even for St. Pol de Léon, Sommerfelt (1921), adjacent to Cléder (Fave), while Pluigneau (Hingant) is farther off.
} 
Paeet em eus ... gant ma gwenneien ma-unan

paid R.1s have with my pennies my one

I've paid with my own money. (Menard \& Kadored 2001 s.v. unan)

28) Beza laosket $\mathbf{P R O}_{\text {arb }} d^{\prime}$ en em geita an-eun a vez kavet displijuz.

be left to REFL adjust IMP-one $\mathrm{R}$ is $(\mathrm{H}) .3 \mathrm{~s}$ found unpleasant

One finds it unpleasant to be left to manage by oneself. (Ar Gow 1963)

29) Madou an nesa peurliesa a gaver gwelloh evidre an-eun.

goods IMP closest generally $R$ find.IMP better than ones IMP-one

One usually finds the goods of others better than one's own. (Ar Gow 1963)

30)

Ne vez ket an-unansur eus evuhez

NEG be(H).3s not IMP-one sure from his life

One is not sure of one's life. (Menard \& Kadored 2001, s.v. an unan).

In an unan, the definite article looks like an impersonal possessor proclitics. Two grammars of NW dialects, that of Hingant (1868, N-Leon/Treger boundary) and Fave (1998, NW-Leon) use the definite article itself as an impersonal possessor proclitic: independently, 31), and as anaphor to verbal and prepositional $r / d$-forms 32 ), and to arbitrary PRO 33). Usually this impersonal proclitic an is doubled by an unan, but not always, as in 39) below. ${ }^{21}$

Esoh eo ar falz an-unan da vedi. easier is(I).3s IMP sickle IMP-one to harvest One's own sickle is easier to harvest with. (Fave 1998)

32) Muioc'h é kérer ar vugalé ann-unan égét bugalé ar ré-all. more R love.IMP IMP children IMP-one than children the ones-other One loves more one's own children than the children of the others. (Hingant 1868: 194) Arabad eo $\mathbf{P R O}_{\text {arb }}$ beza re striz e-r heñver an unan. ${ }^{22}$ forbidden is(I).3s be too strict in-IMP respect IMP one One mustn't be too strict with oneself (lit.: in one's respect). (Fave 1998)

\footnotetext{
${ }^{21}$ Fave's but not Hingant's grammar has prepositional $r$-forms. Other grammars like Kervella (1995 [1947]) do not mention this use of the definite article, and of dictionaries most do not do so explicitly, with the exception of Merser (2009, s.v. son), but examples of an unan usually include the type ar falz an-unan (Menard \& Kadored 2001; Merser 2009, s.v. an unan), which requires the apparent definite article as impersonal possessor.

${ }^{22}$ Note that $e-r$ here is $e$ 'in' $+a r$, not the impersonal form of the preposition, which is ennor.
} 
Fave shows the apparent definite article to be a possessor pronoun from its meaning and morphophonology, to which we add an argument from unan-forms. First, the definite article is a not felicitous translation in 31), 32), and strictly impossible in 33), where the noun heñver is the fixed part of a complex preposition and must occur with a possessor, like English on X's behalf. Second, ar vugalé ann-unan in 31) can only be analysed with an unan as an unan-form doubling ar as its possessor controller. It cannot be analysed as possessum ar vugale 'the children' and possessor an unan in the construct state, since the possessum cannot take the definite article. Third and most strikingly, in Fave's grammar the impersonal possessor is not in fact morphophonologically identical to the definite article. The definite article lenites following feminine singulars, falz [f] - ar falz [v] 'sickle', and most masculine plurals, bugale - ar vugale 'children'. The impersonal possessor does not, so that falz is unlenited in 31), and we get the contrast in 34). Interestingly, in Hingant's grammar the impersonal possessor does trigger the same lenition as the definite article, 32).

Aezeo kared ar vugale. Aesoh eo c'hoazkared ar bugale an-unan. easy is(I).3s love the children easier is(I).3s still love IMP children IMP-one It is easy to love children. It is easier still to love one's own children. (Fave 1998)

The impersonal possessive an comes with its share of mysteries. In the first place, we do not know the origin of the an unan impersonal. ${ }^{23}$ The very existence of possessed ma unan 'my one' leads to the expectation of an unan 'the one', since possessor proclitics are in the same structural position as the definite article: they

\footnotetext{
${ }^{23}$ Unan has the range of meanings of one (Payne et al., 2013): cardinal 'one', in many varieties generic impersonal one (section 1), and to an extent varying with variety a pro-NP, pez unan 'which one', eur mell unan 'a large one' (Goyat 2012). However, the unan of unan-forms is identical with unan 'one' only in some varieties: Hingant's and Fave's grammars and elsewhere (standard Breton; in varieties, e.g. Sommerfelt 1921: §250; Le Dû 2012: 54). It other varieties unan-forms use rather the distinct hunan (e.g. central Humphreys 1995: 326; Wmffre 1998: 2.16; Favereau 1984: III.1.h vs. e, 1997: §258, 2000 s.v. hunan; SE-Gwened Cheveau 2007: 5.1.2; SW-Kerne Goyat 2012: 9.2.4.3). Both sets of varieties have counterparts to unan-forms with other cardinals, hon daou 'our two'. The historical situation is debated (Lewis \& Pedersen 1937: §326, §276 vs. Schrijver 1997: 83). For a comparative picture, in Middle Welsh we get un 'one' versus possessed hun(an)-forms, while counterparts with other cardinals do not use quite the same pronominal prefixes (Morris Jones 1913: §160).
} 
occupy the same place in the DP and both are excluded on the possessum in construct state. However, that does not give an unan its impersonal meaning, as anaphor 29) or alone 30). The recruitment of the definite article an as possessive proclitic generally seems to be a development additional to the rise of impersonal an unan. Possibly, it was aided by inalienable possession 35), where the definite article is a pronominal anaphor, as but more rarely than in French (q.v. Guéron 1985; Vergnaud \& Zubizarretta 1992). With an impersonal subject, 35) would look like an is anaphoric to it. The origin of Fave's nonlenition might be kinship nouns like mamm 'mother'; it usually lenites to ar vamm, but lenition can be idiosyncratically suspended (Menard \& Kadored 2001; Merser 2009, s.v. mamm). It is of interest but of unclear import that in neither Hingant's nor Fave's grammar has the object proclitic system developed an impersonal, though possessor and object proclitics have much influenced each other since Middle Breton, to near convergence in Table 1 (Hemon 2000; ARBRES: Contraste entre les déterminants possessifs et les clitiques objets).

den ebed ne sav andorn

person none NEG raises the hand

No one raises his hand. (Hélias n.d.b) $\rightarrow$ ? Ne saver ket andorn

NEG raise.IMP not the hand

One does not raise one's hand.

As with the $r$-form of prepositions, the impersonal possessive an has the potential to contribute to the understanding of $\rho$-impersonals because it is not a subject, and as with prepositions, we do not know whether it exists outside generic contexts. It is also telling in another way. We have seen that $\rho$-impersonals are phideficient and cannot antecede phi-complete personal pronouns. The definite article contrasts with possessor proclitics in not having any phi-features of its own. That makes it an ideal candidate for recruitment as a phi-less anaphor to the verbal $r / d \rho$ impersonal and as an $\rho$-impersonal itself.

Not all grammars have developed the definite article to the impersonal possessor. Some use the 3s masc. possessor proclitic $e$, anaphoric to both verbal $r / d$ forms 36) and to arbirary PRO 37). There has also been noted the existence of apparent $1 p$ anaphora to the $r / d$-form in 38 ). 
El léach ma klaskeur hé c'hounid hé-unan, énô é kouezar garantez. in.the place as search.IMP his gain his-one, there $R$ fall.3s the love Where one looks for one's own interest love vanishes. (Troude 1842, s.v. cesser)

Atao a gaver eost ann amezek gwelloc'h evit hon-hini. always $R$ find.IMP harvest IMP/the neighbour better for our-one One always finds the neighbour's harvest better than one's own. (Hemon 2000: §58)

Fave $(1943: 371,1998)$ views the $3 s$ possessor anaphoric to impersonals as a gallicism, in terms that suggests it is simply not present in his variety:

39) Let us take the sentence: Red eo kaoud unan bennag war e dro [necessary is(I).3s have one some on his turn 'One must have someone around one' -MR/MJ]. One thinks at first that it's someone else than "oneself" [...] the impersonal form of the possessive does exist. It is the form AN, AL, AR: Red eo kaoud unan bennag war AN tro [note absence of lenition of fem. tro 'turn', vs. an dro 'the turn' -MR/MJ].

The $3 \mathrm{~s}$ possessor has no impersonal use except when anaphoric to another impersonal, and elsewhere $3 \mathrm{~s}$ does not seem to be used even as anaphor to impersonals. ${ }^{24}$ In view of this, Fave's ascription of the use to French influence may be right; as we will see below, in French the apparently 3s possessor is in fact phi-less when anaphoric to the $\rho$-impersonal. We turn now generally to anaphoric dependencies between impersonal $r / d$-forms and personal pronouns.

\footnotetext{
${ }^{24}$ However, for the eighteenth century, Rostrenen (2008 [1738]: 62) does give prepositions inflected for $3 s$ as anaphoric to the $r / d$-form: gaou a rear oud-hâ e-unan or oud e-unan wrong R do.IMP to.3s his-one or to his-one 'One does wrong to oneself, On se fait tor à soi-même', and Troude (1842), Moal (1890) give give such examples with arbitrary PRO as subject of infinitive dictionary entries. Other sources use an unan if they do not have $r$-forms in prepositions, thus Moal sonjal ervad var ann-unan think well on IMP-one 'think about oneself' vs. komz out-han he-unan talk to.3s his-one 'talk to oneself', or else use other impersonals, Rostrenen an den.
} 


\section{Phi-features of pronominal anaphora}

The typical behaviour of $\rho$-impersonals as antecedents in anaphoric dependencies may be illustrated with French on. Nonspecific on is deficient for person and number, and can be the antecedent only of other phi-deficient expressions. These include another on, phrasal reciprocals that lack person, and pronouns in $s$ - that lack phi-features entirely, and PRO. 40) is a telling example: the impersonal on must range over pluralities to antecede the reciprocal, as must the possessor ses of common interests though independently of on, ses is a only $3 \mathrm{~s}$ possessor. All other personal pronouns are phi-complete and cannot be anaphoric to on without change of meaning: in 40), the s-pronouns cannot be replaced by $3 p$ eux 'them', leurs 'their', though on ranges over pluralities that exclude the speaker and addressee. ${ }^{25}$

\section{0) Dans le film, il y a quatres couples, et}

on $_{i} \boldsymbol{s e}_{i} \quad$ parlait les uns aux autres

In the film, there were four couples, and IMP REFL talked the ones to.the others

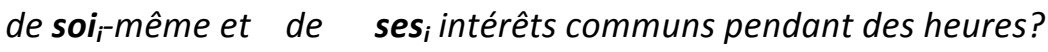
about S-self and about S- interests common for hours In the film, there were four couples, and people talked to each other about themselves and their common interests for hours? (R\&)

Other expressions only seem to be anaphoric, thanks to similar meaning, notably kind and generic $1 p / 2 p$ pronouns as in 41 ). Here generic $2 p$ vous seems anaphoric to on, though only at a distance, because their meanings are similar enough. This is not always available, because on has a broader meaning, including in 26) when the matrix clause includes a deictic $2 p$ vous, or 41$)$.

\footnotetext{
${ }^{25}$ See R\&J for extensive development of this point. The hypothesis that $\rho$-impersonals are phi-deficient is seminally advanced in Cinque (1988) for person, while Egerland (2003) argues that their exponents are entirely phi-less; phi-deficiency of anaphora is used to account for the limits of anaphoricity to $\rho$ impersonal in Albizu (1998) for Basque and McCloskey (2007) for Irish, allowing antecedence of phi-less reciprocals but not phi-complete reflexives.
} 
Dialectologia. Special issue, $\boldsymbol{V}$ (2015), 261-292.

ISSN: 2013-2247

41)

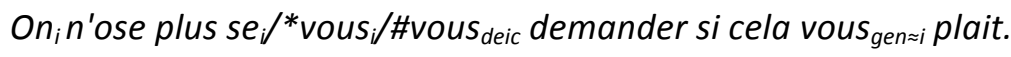

One $_{\mathrm{i}}$ doesn't dare ask oneself $\mathrm{i} /$ *yourself $_{\mathrm{i}} /$ \#you $_{\text {deic }}$ anymore if it makes you $\mathrm{gen} \approx \mathrm{i}_{\text {happy. }}$

(Grevisse, 2008: §754)

In contrast, specific on has the phi-properties of a $1 p$ pronoun in anaphoric relationships and it can combine with strong pronoun nous as an emphatic doublee, for which there is no impersonal counterpart, save that the reflexive-reciprocal clitic remains se because verb agreement remains 3s.

In Breton, anaphora to the $r / d$-form of the verb as given in grammars and evidenced in texts are also limited to ones plausibly phi-deficient:

- Controlled PRO, getting phi-features from its antecedent, and arbitrary PRO, plausibly itself reflecting a phi-deficient $\rho$-impersonal.

- Reflexive-reciprocal clitic en em, invariant and used for antecedents of any person and number.

- Phrasal reciprocal, differentiating gender, and floating quantifiers, invariant, both used with any antecedent.

- Prepositional $r$-forms, invariant and impersonal.

- Possess proclitic an and doubling an unan, invariant and impersonal.

- 3s possessors, arguably under the same phi-less analysis as French.

- Remote kind/generic $1 \mathrm{p} / 2 \mathrm{p}$ pronouns, 38 ), in the same way as 41$)$.

We have carried out a pilot study with four speakers with verbal $r / d$-forms: most extensively with the couple $A$ and $Y$ (NW-Leon), partly with A-M and L (W-Kerne). Our focus was those pronominal anaphora that are strictest about requiring phi-identity with their antecedent: coargument DPs/PPs and their possessors, and particularly inherent/inalienable reflexives like be at one's ease, be beside oneself, take on oneself, which resist even the easiest phi-mismatches with their antecedent.

42) L'équipe est à son/*leur aise.

The team is at its $/ *$ their ease. 
Example 43) serves as a synopsis of A's grammar. There is a bewildering freedom of pronominal anaphora to the verbal $r / d$-form: only $1 \mathrm{~s}$ and $2 \mathrm{~s}$ are excluded. In French, by contrast, only the phi-less possessor son is possible, if we set aside specific on 'we' on the "nurse" use of we which is odd here. However, behind 43) there appear to be the expected limitations on $\rho$-impersonals, covered up by developments in originally different grammars that converge in A's.

43) [A visits a friend, his wife welcomes him and says the friend is on the balcony with a great cocktail; A says to his friend:]

Klevetameus emeur en $\varnothing /$ hon /hoc'h/o/e/*da / ma eas; gwir eo? heard R.1s have is(L).IMP in the /our/your(pl)/their/his/your(sg)/my ease, true is(I).3s I have heard that someone's taking it easy, is it true? $\{$ A.Q.2\}

cf. J'ai entendu qu'on est à $I^{\prime} /\left({ }^{*}\right)$ notre $/{ }^{*}$ votre $/{ }^{*}$ leur $/$ son $/{ }^{*}$ ton $/{ }^{*}$ mon aise, c'est vrai?

A has access to a childhood grammar close to that described by Fave, possessing prepositional $r$-forms beside verbal $r / d$-forms, and the an-unan doublee of both, seen in 44), as well as the an possessor seen later in 45). These reflect the expected phideficient anaphora.

44) Arskiant-prenet eo ar pezh a zesker dreizeur an-unan. the experience is (I).3s the piece R learn.IMP by.IMP IMP-one Experience is what one learns on one's own. $\{A . Q 2\}$

45) [A psychoanalyst to another about her new group of patients] Gwelout a ran mat emeur o vond doun enneur an-unan. see $\quad R$ do.1s well is(L).IMP at go deep in.IMP IMP-one I see well that people(they) dwell deep down, but never enough. \{A.Q2\}

In A's most-used grammar however, 1p personal pronouns are the anaphora to verbal $r / d$-, and even prepositional $r$-forms of the childhood grammar can be doubled 
Dialectologia. Special issue, $\boldsymbol{V}$ (2015), 261-292.

ISSN: 2013-2247

by $1 p$ unan-forms. $1 p$ is also anaphoric to verbal $r / d$-forms for $A-M$ and $L$, who lack prepositional $r$-forms and an-possessors. We have already seen this possibility in 38 ).

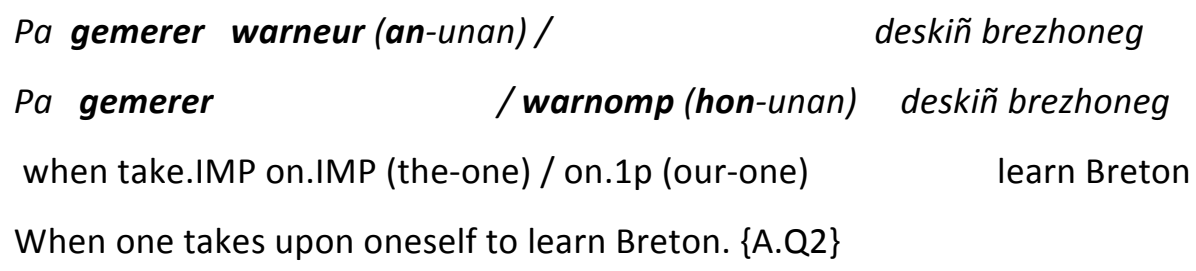

48) Muioc'h e karer eost an amezog eged an-hinihon-unan. more $\quad \mathrm{R}$ like.IMP harvest the neighbour than the-one our-one One likes better the neighbour's harvest than one's own. $\{$ A.Q2\}

49) [translation task introduced by the idea of being one's own boss]

Pa labourer evidomp hon-unan, e labourer diouzh hon holl galon. $\{$ A.Q2\}

Pa labourer evidomp-(ni) hon-unan, e labourer mat. $\{\mathrm{A}-\mathrm{M} . \mathrm{Q} 1\}$

when work.IMP for.1p-(us) our-one $\mathrm{R}$ work.IMP from our all heart / well When one works for oneself, one works with all one's heart/well.

However, these $1 \mathrm{p}$ seem to have become phi-deficient for person and number. Strikingly, for all three speakers $1 p$ anaphora to $r / d$-forms are available even when the speaker is excluded, when English we is banned and French on cannot have $1 p$ anaphora (R\&J):

50) [Goldilocks context:]

$\begin{array}{llll}\text { O kousket } & \text { emeur } & \text { hon/*e-unan em } & \text { gwele! }\{\text { A.Q2\} } \\ \text { O kousket } & \text { emeur } & \text { ?hon/*e-unan barzh va } & \text { gwele! }\{\mathrm{A}-\mathrm{M} . \mathrm{Q} 1\} \\ \text { at sleep } & \text { be(L).IMP } & \text { our-one in my bed }\end{array}$

Someone is sleeping by themselves in my bed!

51) [A psychoanalyst to another about her new group of patients]

Gwelout a ran mat emeur o vond don e diabarzh hon-unan...

see $\quad \mathrm{R}$ do.1s well is(L).IMP at go deep in interior our-one

I see well that they/people have delved deep within themselves. $\{A-M . Q 1\}$ 
52) ... e kemerer ur sakre sammad war hom c'hein.

... R take.IMP a mighty burden on our back ... that someone/people carry a mighty burden on their backs. $\{L . Q 1\},\{A-M . Q 1\}$

More remarkably still, for $A$ even non-anaphoric $1 p$ inflection and pronouns seem to have lost the usual commitment of $1 p$ pronouns to speaker inclusion.

53) [A policeman looking for a missing person finds traces of a fight:]

Amañ omp kouezhet!/Kouezhet eur amañ.

here is(I).1p fallen / fallen is(I).IMP here

Someone fell here. $\{$ A.Q2\} (The only difference A can imagine between is that surprise is more salient with $1 p$.)

54) Gwelet a ran hon beus graet eus hor gwellañ. see $\quad$ R do.1s R.1p have done of our best

I see that someone/people did their best. $\{$ A.Q2\}

These results suggest that $1 \mathrm{p}$ forms have become grammaticalised as phi-less pronouns, possibly beside also allowing 1 p phi-specification. The development might be due to the same reasons as the tendency for $\rho$-impersonals to gain $1 p$ as their specific use: Cinque (1988) suggests that $1 p$ is closest to the meaning of the impersonal because it is inclusive of all persons. French on generalised the specific $1 p$ use mostly from the late nineteenth on (King et al. 2011), and French in turn might have influenced Breton 1p forms to create phi-deficient impersonals in these grammars. There is an important gap in the impersonal use of $1 p$ : the $1 p$ emphatic enclitics cannot easily double $r / d$-forms, 55). However, the doubling does not seem categorically impossible, and the difficulty might rather reflect the rarity of strong emphatic forms of impersonal pronouns generally (Bolinger 1979). ${ }^{26}$

\footnotetext{
${ }^{26}$ Of interest is the NW Leon dialect of Ouessant in the texts in Gouedig (1984): $1 p$ on unan is used as the unan-form doubling $1 \mathrm{~s}$ in all cases, and the sole occurrence of $1 \mathrm{~s}$ ma unan is exempt (other unanforms keep their phi-features): am-eus gwelet on-unan gwechall 'that have.1s seen myself once' ; din on-unan 'to.1s myself'; me yoa on-unan 'I was.3s [by] myself', Med ya, laren-me, on-unan emaon zur 'But yes, said.1s-I, myself am.1s certain'; versus An dra-ze zepande, ma-unan a gaozee brezoneg, 'That depended, myself PRT spoke.3s Breton'. The development recalls older French je sommes $=$ nous sommes with $1 \mathrm{~s}$ je for $1 \mathrm{p}$ nous plus $1 \mathrm{p}$ verb (King et al. 2011).
} 
Dialectologia. Special issue, $\boldsymbol{V}$ (2015), 261-292.

ISSN: 2013-2247

55) ?/*Bremañ, anavezout a reer-ni ac'hanout!

now know $R$ do.IMP-we of.2s

Now people know you! V\{A.Q1\}, *\{A.Q2\}, ?/*\{A-M.Q1\}

As in French, generic $2^{\text {nd }}$ person may seem anaphoric to $r / d$-forms at a distance, 56), but also in except-phrases, 57)-59) where it is unavailable in French. In French, the generic $2^{\text {nd }}$ person linked to on is usually $2 p$, though 2 s occurs. In $A^{\prime}$ 's Breton, $2 s$ seems to be the unmarked generic $2^{\text {nd }}$ person, and it links to verbal $r / d$-forms, but $2 p$ also occurs:

56) Pa labourer evideur hon-unan, e labourez / labourer a holl galon.

when work.IMP for.IMP our-one $\mathrm{R}$ work.2s/IMP from all heart

When one works for oneself, one works / you work with full heart. \{A.Q2\}

57) Ne weler ket mat nemet da-unan ha da dud.

NEG see.IMP not well only your(sg)-one and your(sg) people

One only sees well oneself and one's folks. (lit. yourself and your folks) \{A.Q1\}

58) Gwelloc'h e kaver atav eost an amezog eget da eost da-unan.

better R find.IMP always harvest the neighbour than your(sg) harvest your(sg)-one One finds better the neighbour's harvest than one's own [lit. your own] \{A.Q1\}

59) Paouroc'h egedoc'h/egedor e kaver atav.

poorer than.2p/IMP R find.IMP aways

One always finds someone poorer than oneself. $\{$ A.Q2 $\}$

$2 p$ may have itself grammaticalised as a phi-deficient impersonal. When the $r / d$ form is absent in a grammar, $2^{\text {nd }}$ person is left as the sole generic impersonal pronoun, but there seems furthermore to have been interaction between $2 p-c^{\prime} h[x]$ and impersonal $-r[r]>[R]$ forms due to their partial or complete phonological convergence. Already Ernault (1897) reports $2 p-c^{\prime} h$ inflections extending into the space of $r / d$ inflections, and the expansion includes the simple past which is not generic: older 
kanjeur, kanjot, but also kanjoc'h 'on chanta, IMP sang'. ${ }^{27} \mathrm{~A}^{\prime}$ s wife $\mathrm{Y}$ lacks $r / d$ inflections and perceives them as $2 p$ inflections, collapsing $-[x]$ and $-[R]$. A makes the distinction phonologically and morphologically. However, he does allow $2 p$ as the local anaphor to $r / d$-forms in 43). 2 s remains impossible locally.

In 43), A also allows $3 \mathrm{~s}$ and $3 \mathrm{p}$. We have already noted the $3 \mathrm{~s}$ possessor anaphoric to $r / d$-forms in 37) and the potential influence of French. In French, son is both the 3s possessor generally, and the phi-less possessor anaphoric to on. The use of 3s in Breton may be modelled on this syncretism, but it may be an independent development. For A, it is a rare option even as possessor, 60), and absent otherwise, 50). The $3 p$ possessor in 60 ) is more common. A possible analogy is the options in English as possessor of one in 61) British one, older US his, more frequently nowadays the so-called epicene they.

60) $P a$ vezer en hon/*e / ?o eas e kaner gwelloc'h. when is(L).IMP in our / *his / ?their ease R sing.IMP better One sings better when at ease. $\{A . Q 2\}$
a) One had to live one's own life. (C.S. Lewis, That Hideous Strength)

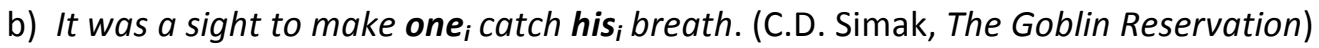
c) Guidelines don't mean a whole lot when one fears for their $_{i}$ own survival.

The grammar of $A$ thus ends up allowing a remarkable latitude for local anaphora to the $\rho$-impersonal of the verbal $r / d$-forms, but for explicable reasons:

- Phi-deficient prepositional $r$-forms and possessor an impersonals of his childhood grammar.

- 1p developing into a phi-deficient impersonal, found elsewhere.

- $2 p$ developing into a phi-deficient impersonal, widespread, through A's wife's grammar.

-3s as phi-deficient impersonal perhaps from French, widespread and marked for $A$.

\footnotetext{
${ }^{27}$ See section on prepositional $r$-forms, and citation there to Ernault (1897) who already reports mix of $r$ and $2 p c^{\prime} h$ forms the verbal impersonal. A distinguishes final $-c^{\prime} h[x]$ and $-r[R]$; his wife does not hear the difference.
} 
Dialectologia. Special issue, V (2015), 261-292.

ISSN: 2013-2247

- $3 p$ so far unreported but with analogue in English epicene they.

- No $1 \mathrm{~s} / 2 \mathrm{~s}$, save generic $2 \mathrm{~s}$ at a distance.

\section{Envoy}

The Breton inflectional impersonal is both familiar, in the light of $\rho$-impersonals like French on, and surprising, thanks to grammatical and sociolinguistic particularities of Breton. Grammatically, there have taken place extensions of the verbal impersonal to create counterparts in prepositional and nominal inflection. This development is another piece of evidence for the parallelism of verbal, prepositional, and nominal inflections in Celtic. In the theory of impersonals, it makes for a rare opportunity to understand the nature of the robust but still mysterious restriction of $\rho$-impersonals to subjects. Sociolinguistically, the history of Breton in the twentieth century has been one of growing dialectal disintegration and differentiation, as a once contiguous language community has broken up into islets each changing unchecked by former neighbours yet still meeting up at times. A's remarkable grammar is one outcome. It is at first sight a checkered collection of impersonalised uses of personal pronouns and so of unexpected anaphora to the $\rho$-impersonal. Yet each impersonalisation seems to be a natural development, and their confluence leaves an untouched core where the expected anaphoric restrictions of the phi-less $\rho$-impersonal shine through.

\section{References}

Note: bibliographical information on grammars/dictionaries not listed here can be found on ARBRES: http://arbres.iker.cnrs.fr/index.php/Bibliographie

ALBIZU, Pablo (1998) "Impersonal constructions of Basque revisited", Handout from Mayfest '98, University of Maryland, July 6-8, 1998.

ANDERSON, Stephen (1982) “Where's morphology?”, Linguistic Inquiry, 13, 571-612. 
ANDREWS, J. Richard (2003) Introduction to Classical Nahuatl, Norman: University of Oklahoma Press.

ARBRES: http://arbres.iker.cnrs.fr.

Bolinger, Dwight (1979) “To catch a metaphor: You as norm", American Speech, 54, 194-209.

BORSLEY, Robert D. \& Janig STEPHENS (1989) "Agreement and the position of subjects in Breton", Natural Language and Linguistic Theory, 7, 407-427.

Borsley, Robert D., Maggie Tallerman \& David WiluIs (2007) The syntax of Welsh, Cambridge: Cambridge University Press.

CABREDO HOFHERR, Patricia (2008) "Les pronoms impersonnels humains", Modèles linguistiques, XXIX-1(57), 35-56

CRAHE, Maxime (2013) Le breton de Languidic, Doctoral dissertation, Rennes II. [SE-Gwened].

CHEVEAU, Loic (2007) Approche phonologique, morphologique et syntaxique du breton du grand Lorient, Doctoral dissertation, Rennes II. [SE-Gwened].

CHIERCHIA, Gennaro (1995) "The variability of impersonal subjects", in E. Bach et al. (eds.), Quantification in natural languages, Dordrecht: Kluwer, 107-143.

CINQUe, Guglielmo (1988) "On si constructions and the theory of Arb", Linguistic Inquiry, 19, 521-581.

CLACKSON, James (2007) Indo-European linguistics, Cambridge: Cambridge University Press.

CowGILL, Warren (1983) "On the prehistory of Celtic passive and deponent inflection", Ériu, 34, 73-111.

EgerLAND, Verner (2003) "Impersonal pronouns in Scandinavian and Romance", Working Papers in Scandinavian Syntax, 71, 75-102.

ERNAULT, Emile (1884) Dictionnaire étymologique du moyen Breton, Paris.

ERNAULT, Emile (1897) Petite grammaire bretonnne, Saint-Brieuc: Prud-homme.

EVENOU, Erwan (1987) Description phonologique du breton de Lanvenegen, Doctoral dissertation, Rennes II. [S-Kerne].

FALC'HUN, François (1981) Perspectives nouvelles sur l'histoire de la langue bretonne, Union Générale d'Edition: Paris.

FAVE, Visant (1943) "Ar ragano gourfenger "or"”, Feiz ha Breiz, 79, 271-272, 371-3. [NW-Leon].

FAVE, Visant (1986) “Ar stumoù dibersonel e brezhoneg”, Brud Nevez, 93, 69-74. [NW-Leon].

FAVE, Visant (1989) War roudou hor misionerien, Brest: Emgleo Breiz. [NW-Leon].

FAVE, Visant (1998) Notennou yezadur, Brest: Emgleo Breiz. [on-line version has corrections; we incorporate a slightly different French version, 2004, Notes de grammaire bretonne, C. Miossec (ed.), Cléder: Mairie de Cléder] [NW-Leon]. 
Dialectologia. Special issue, V (2015), 261-292.

ISSN: 2013-2247

FAVEREAU, Francis (1984) Langue quotidienne, langue technique et langue littéraire dans le parler et la tradition orale de Poullaouen. Doctoral dissertation, Rennes II. [central].

FAVEREAU, Francis (1997) Grammaire du breton contemporain, Morlaix: Skol Vreizh. [all].

FAVEREAU, Francis (2000) Geriadur ar brezhoneg a-vremañ, Morlaix: Skol Vreizh. [all].

Giacalone RAmat, Anna \& Andrea Sansò (2007) "The spread and decline of indefinite manconstructions in European languages", in P. Ramat \& E. Roma (eds.), Europe and the Mediterranean as Linguistic Areas, Amsterdam: John Benjamins, 95-131.

Giacalone RAmAT, Anna \& Andrea SAnsò (2011) "From passive to impersonal. A case study from Italian and its implication", in A. Malchukov \& A. Siewierska (eds.), Impersonal constructions, Amsterdam: John Benjamins, 189-228.

GouedIG, Patrig (1984) Enez-Eusa: Eñvoriou tud Eusa, Brest: Emgleo breiz. [NW-Leon].

GoYAT, Gilles (2012) Description morphosyntaxique du parler breton de Plozévet (Finistère), Doctoral dissertation, Rennes II. [SW-Kerne].

Gros, Jules (1974 [1984]) Le trésor du breton parlé III, Lannion: Barr-Heol. [NE-Treger].

GREVISSE, Maurice \& André GoOSSE (2008) Le bon usage, Bruxelles: De Boeck \& Larcier.

GUÉRON, Jacqueline (1985) "Inalienable possession, PRO-inclusion and lexical chains", in Jacqueline Guéron, Jean-Yves Pollock \& Hans Obenauer (eds.), Grammatical representation, Dordrecht: Foris, 43-86.

GUILLEVIC, Augustin \& Pierre LE Goff (1986) Grammaire bretonne du dialecte de Vannes, Brest: Ar Skol Vrezhoneg- Emgleo Breiz. [original 1902] [SE-Gwened].

HEIM, Irene (1982) The semantics of definite and indefinite noun phrases. Doctoral dissertation, MIT.

HÉLIAS, Per-Jakez. n.d.a. Ar biz er pinser, CRBC. [on-line] [SW-Kerne].

HÉLIAS, Per-Jakez. n.d.b. Jobig an Turluter, CRBC. [on-line] [SW-Kerne].

HEMON, Roparz (2000) Yezhadur istorel ar Brezhoneg, Rennes: Hor Yezh. [original 1975].

HEWITT, Steve (2002) "The impersonal in Breton", Journal of Celtic Linguistics, 7, 1-39.

HINGANT, Jean (1868) Éléments de la grammaire bretonne, Tréguier: A. Le Flem. [NLeon/Treger].

HUMPHREYS, Humphrey Lloyd (1995) Phonologie et morphosyntaxe du parler breton de Bothoa en Saint-Nicolas-du Pélem (Côtes d'Armor), Brest: Emgleo Breiz. [central].

JouitTeAU, Mélanie (2005) "Nominal Properties of $v$ Ps in Breton, A hypothesis for the typology of VSO languages", in A. Carnie et al. (eds.), Verb first: On the syntax of verb-initial Languages, Amsterdam: John Benjamins, 265-280. 
JouItTEAU, Mélanie (2015) “Pronoms impersonnels dans le breton vannetais de Loeiz Herrieu: Syntaxe, sémantique et usages en concurrence avec le passif", La Bretagne Linguistique, 19, 261-280.

JouItTEAU, Mélanie \& Milan RezAC (2006) "Deriving the Complementarity Effect: Relativized Minimality in Breton agreement", Lingua, 106, 1915-45.

JouItTEAU, Mélanie \& Milan Rezac (2008) "From mihi est to have across Breton dialects", Rivista di Grammatica Generativa, 32, 161-178.

KAYNE, Richard (2000) Parameters and universals, Oxford: Oxford University Press.

KAYNE, Richard (2010) Comparisons and contrasts, Oxford: Oxford University Press.

KING, Ruth, France MARTINEAU \& Raymond MOUgEON (2010) "The interplay of internal and external factors in grammatical change: First-person plural pronouns in French", Language, 87, 470-509.

LE BAYON, A.-M. (1986 [1878]) Grammaire bretonen du dialecte de Vannes, Rennes: Hor Yezh. [SE-Gwened].

LE COADIC, Ronan (2010) Brezhoneg Goueloù, An Alarch. [NE-Goueloù].

LECLERC, Louis (1986 [1906]) Grammaire bretonne du dialecte de Tréguier, Emgleo Breiz: Ar Skol Veur. [NE-Treger].

LE DÛ, Jean (2012) Le trégorrois à Pougrescant, Brest: Emgleo Breiz. [NE-Treger].

LE RouX, Pierre (1957) Le verbe breton, Rennes: Plihon.

LE Roux, Pierre (1927) Atlas linguistique de la Basse-Bretagne, Rennes: Plihon. [all].

LeWIS, Henry \& Holger Pedersen (1937) A concise comparative Celtic grammar, Göttingen: Vandenhoeck \& Ruprecht, Supplement 1961.

KeRVELLA, François (1995 [1947]) Yezhadur bras ar brezhoneg, La Baule: Skridoù Breizh. [WKerne/Leon].

MALAMUD, Sophia (2012) "Impersonal indexicals", Journal of Comparative Germanic Linguistics, $14,1-48$.

McCloskeY, James \& Ken HALE (1983) "On the syntax of person-number inflection in Modern Irish", Natural Language and Linguistic Theory, 1, 487-533.

MCCLOSKEY, James (2007) "The grammar of autonomy in Irish", NLLT, 25, 825-857.

MCCLOSKEY, James (2011) "Irish impersonals in context", talk presented at the Workshop on Impersonal Pronouns, Paris, CNRS-University of Paris 8, September 20, 2011.

MenARD, Martial \& Ywan KADORED (2001) Geriadur Brezhoneg, Plougastell-Daoulas: An Here.

MERSER, Andreo (2009) Ar Geriadur, dictionnaire Breton-Français / Français-Breton, Brest: Emgleo Breiz. 
Dialectologia. Special issue, V (2015), 261-292.

ISSN: 2013-2247

MendikoetXeA, Amaya (2008) "Clitic impersonal constructions in Romance", Transactions of the Philological Society, 106, 290-336.

MEYER, Roland (2010) "Reflexive passives and impersonals in North Slavonic languages", Russian Linguistics, 34, 285-306.

MOAL, Jean (1890) Supplément lexico-grammatical au dictionnaire pratique français-breton du colonel A. Troude en dialecte de Léon, Landerneau: Desmoulins. [NW-Leon].

MORRIS JONES, John (1913) A Welsh grammar, historical and comparative, Oxford: Clarendon.

Morvan, Gabriel (1894) Buhez ar zent, Quimper: Kerangal. [W-Leon/Kerne].

MoRVANNou, Fanch (1978) Le breton sans peine, vol. 1, Chennevières sur Marne: Assimil.

MoRvannou, Fanch (1980) Le breton sans peine, vol. 2, Chennevières sur Marne: Assimil.

NEDELEC, Pierre Jean (1943) Yezadur ar brezoneg, Lesneven. [W-Kerne].

OUKADA, Larbi (1982) “On on", The French Review, 56, 95-105.

Payne, John, Geoffrey K. Pullum, Barbara C. Scholz \& Eva Berlage (2013) “Anaphoric one and its implications", Language, 89, 794-829.

PLOURIN, Jean-Yves (1982) Description phonologique et morphologique comparée des parlers bretons de Langonnet (Morbihan) et de Saint-Servais (Côtes-du-Nord), Doctoral dissertation, Université de Rennes II. [central].

PLONEIS, Jean-Marie (1983) Au carrefour des dialectes bretons - Le parler de Berrien, Paris: SELAF. [W-Kerne].

PRESS, Ian (1986) A grammar of modern Breton, Mouton: Berlin.

Press, Ian (2010) "Breton", in M. J. Ball et al. (eds.), The Celtic languages, Routledge: London, 427-487.

ReZAC, Milan \& Mélanie JouItTEAU (2015) The $\rho$-impersonal on: Nature and consequences of referential deficiency. Ms., CNRS-IKER.

ROSTRENEN, Gregoire de (2008 [1738]) Grammaire françoise-celtique ou françoise-bretonne, Quimper: Al Lanv.

ROUVERET, Alain (1991) Functional categories and agreement, The Linguistic Review, 8, 353-87.

SCHLENKER, Philippe (2004) "Person and binding", Italian Journal of Linguistics, 16, 155-218.

SCHRIJVER, Peter (1997) Studies in the history of Celtic pronouns and particles, Maynooth: National University of Ireland.

SEITE, Visant (1985) Ar marh reiz, Brest: Emgleo Breiz. [NW-Leon].

SEITE, Visant (1998) O pourmen dre Vreiz-lzel, Brest: Emgleo Breiz. [NW-Leon]. 
SIEWIERSKA, Anna (2011) "Overlap and complementarity in reference impersonals", in A. Malchukov \& A. Siewierska (eds.), Impersonal constructions, Amsterdam: John Benjamins, 57-89.

SOMMERFELT, Alf (1921) Le breton parlé à Saint-Pol-de-Léon, Paris: Champion. [N-Leon].

StePHENS, Jannig (1990) "Non-finite clauses in Breton", in Martin J. Ball et al. (eds.), Celtic linguistics, Amsterdam: John Benjamins, 151-166.

STUMP, Gregory T. (1984) “Agreement vs. incorporation in Breton", Natural Language and Linguistic Theory, 2, 289-348.

STUMP, Gregory T. (1989) "Further remarks on Breton agreement", Natural Language and Linguistic Theory, 7, 429-471.

TERNES, Elmar (1970) Grammaire structurale du breton de l'lle de Groix, Heidelberg: Carl Winter. [SE-Gwened].

TRÉPOS, Pierre (2001 [1968]) Grammaire bretonne, Brest: Brud Nevez. [SW-Kerne].

TROUDE, Amable (1842) Dictionnaire français celto-breton, Brest: Lefournier. [N-Leon].

Vergnaud, Roger \& Maria-Luisa ZubizARRETTA (1992) "The definite determiner and the inalienable construction in French and in English", Linguistic Inquiry, 595-652.

WMFFRE, Iwan (1998) Central Breton, Munich: Lincom. [central]. 